Vol. 2, No. 1, Januari 2014: 41-50

\title{
Riwayat pemberian ASI eksklusif dan MPASI dini sebagai prediktor terjadinya stunting pada baduta di Kabupaten Timor Tengah Selatan, Nusa Tenggara Timur
}

History of exclusive breastfeeding and early introduction of complementary food as predictors of stunting in children under two years old in Timor Tengah Selatan District, Nusa Tenggara Timur

Asweros Umbu Zogara1 ${ }^{1}$ Hamam Hadi², Tony Arjuna²

\begin{abstract}
Background: Stunting is a chronic nutrition problem that reflects failure in growth accumulated before and after birth. Many factors affect the incidence of stunting, among others are exclusive breastfeeding and early introduction of complementary food. The result of a survey carried out by FAO, WFP, and UNICEF in 2010 showed the prevalence of stunting in children under five years old at Timor Tengah Selatan District was $61 \%$.

Objectives: To find out whether history of exclusive breastfeeding and early introduction of complementary food were predictors of stunting in children under two years old at Timor Tengah Selatan District.

Methods: This was observational study by cross sectional design used quantitative and qualitative methods. Qualitative data obtained from focus group discussion. Subject of the study consisted of 408 children 6 to 24 months from 14 villages at Amanuban Barat and Kie Subdistrict selected through simple random sampling technique. Retrieval of data used a structured questionnaire. Stunting in children under two years old measured by indicators of body length by age. Data were analysed by chi square and logistic regression tests with $95 \%$ confident interval.

Results: The proportion of stunting in children under two years old at Amanuban Barat and Kie Subdistrict was $49 \%$. The proportion of exclusive breastfeeding was $61 \%$, and early introduction of complementary food was $36,8 \%$. Exclusive breastfeeding and early introduction of complementary food were not factors affecting the incidence of stunting in children under two years old. Factors more strongly affecting the incidence of stunting in children under two years old were energy intake and characteristics of parents that comprised education and occupation.

Conclusions: Exclusive breastfeeding and early introduction of complementary food were not predictors of stunting in children under two years old at Amanuban Barat and Kie Subdistrict.
\end{abstract}

KEYWORDS: stunting, exlusive breastfeeding, early introduction of complementary food, children under two years old

\begin{abstract}
ABSTRAK
Latar belakang: Stunting merupakan masalah gizi kronis yang dapat memberikan gambaran kegagalan pertumbuhan yang terakumulasi sejak sebelum dan sesudah kelahiran. Faktor-faktor yang turut mempengaruhi kejadian stunting diantaranya pemberian ASI eksklusif dan pengenalan MPASI dini. Hasil survei yang dilakukan FAO, WFP, dan UNICEF tahun 2010 menunjukkan prevalensi stunting pada balita di Kabupaten Timor Tengah Selatan mencapai $61 \%$.

Tujuan: Untuk mengetahui apakah riwayat pemberian ASI eksklusif dan MPASI dini merupakan prediktor terjadinya stunting pada anak di bawah dua tahun (baduta) di Kabupaten Timor Tengah Selatan.
\end{abstract}

\footnotetext{
${ }_{1}$ Pasca Sarjana Ilmu Kesehatan Masyarakat Minat Gizi dan Kesehatan Fakultas Kedokteran Universitas Gadjah Mada, JI. Farmako Sekip Utara Yogyakarta 55281

2 Pasca Sarjana Gizi dan Kesehatan Fakultas Kedokteran Universitas Gadjah Mada, Jl. Farmako, Sekip Utara Yogyakarta 55281
} 
Metode: Penelitian ini merupakan penelitian observasional dengan rancangan cross-sectional yang menggunakan metode kuantitatif dan kualitatif. Data kualitatif yang diperoleh melalui focus group discussion. Sampel penelitian sebanyak 408 anak berusia 6-24 bulan yang berasal dari 14 desa di Kecamatan Amanuban Barat dan Kie yang dipilih menggunakan teknik simple random sampling. Pengambilan data menggunakan kuesioner terstruktur. Stunting pada baduta diukur menggunakan indikator panjang badan menurut umur (WHO 2005). Analisis data menggunakan uji chi square dan regresi logistik dengan $95 \%$ confident interval.

Hasil: Proporsi baduta yang mengalami stunting sebesar 49\%. Proporsi pemberian ASI eksklusif pada baduta sebesar $61 \%$ dan proporsi pemberian MPASI dini sebesar 36,8\%. Pemberian ASI eksklusif dan MPASI dini bukan merupakan faktor yang mempengaruhi terjadinya stunting pada baduta. Faktor-faktor yang lebih kuat pengaruhnya terhadap terjadinya stunting pada baduta adalah asupan energi dan karakteristik orang tua yang meliputi pendidikan dan pekerjaan orang tua.

Kesimpulan: Pemberian ASI eksklusif dan MPASI dini bukan merupakan prediktor terjadinya stunting pada baduta di Kecamatan Amanuban Barat dan Kie.

KATA KUNCI: stunting, ASI eksklusif, MPASI dini, baduta

\section{PENDAHULUAN}

Masalah gizi kurang dan gizi buruk merupakan salah satu masalah kesehatan utama, yang terutama dihadapi oleh negara berkembang. Tahun 2011, 110 juta balita mengalami underweight dan 170 juta balita mengalami stunting (1). Di Indonesia, masalah gizi kurang dan gizi buruk masih merupakan masalah kesehatan yang penting. Salah satu provinsi yang memiliki prevalensi masalah gizi yang tinggi adalah Provinsi NTT. Prevalensi balita yang mengalami gizi kurang dan buruk sebesar $29,4 \%$, sedangkan balita pendek dan kurus sebesar masing-masing 58,4\% dan $13,2 \%$ di provinsi tersebut (2).

Pendek (stunting) merupakan masalah gizi kronis yang dapat memberikan gambaran kegagalan pertumbuhan yang terakumulasi sejak sebelum dan sesudah kelahiran yang diakibatkan oleh tidak tercukupinya asupan zat gizi. Stunting pada 2 tahun awal kehidupan akan mengakibatkan dampak yang sulit diperbaiki, termasuk orang dewasa yang pendek, prestasi sekolah yang rendah, dan pendapatan secara ekonomi akan menurun pada saat dewasa (3). Masalah stunting pada anak dipengaruhi oleh banyak faktor, diantaranya pemberian air susu ibu (ASI) selama 6 bulan pertama $(4,5)$. Pemberian ASI eksklusif merupakan salah satu faktor yang berkaitan dengan pertumbuhan anak $(6,7)$. Pemberian MPASI dini juga merupakan salah satu faktor yang berhubungan dengan stunting pada anak $(8,9)$.
Kabupaten Timor Tengah Selatan (TTS) merupakan bagian dari Provinsi NTT dan memiliki prevalensi stunting pada balita cukup tinggi, yaitu sebesar $57 \%(10)$. Survei yang dilakukan oleh Food and Agriculture Organization (FAO), World Food Programme (WFP), dan UNICEF (2010) menunjukkan prevalensi stunting pada balita di Kabupaten TTS sebesar 61\% (11).

Masalah stunting di Kabupaten TTS ini dapat berdampak buruk bagi generasi penerus sehingga perlu dilakukan penelitian mengenai faktor-faktor yang berhubungan dengan stunting untuk memperbaiki masalah stunting. Berdasarkan penjelasan sebelumnya, pemberian ASI eksklusif dan umur pemberian MPASI berhubungan dengan stunting, sehingga penulis tertarik untuk melakukan penelitian mengenai pemberian ASI eksklusif dan MPASI dini sebagai prediktor terjadinya stunting pada baduta di Kabupaten TTS.

\section{BAHAN DAN METODE}

Penelitian ini merupakan jenis penelitian observasional kuantitatif yang menggunakan desain cross-sectional. Penelitian ini didukung dengan pendekatan kualitatif yang diperoleh melalui focus group discussion (FGD). Penelitian ini dilaksanakan pada bulan Juli 2012 di 7 desa di Kecamatan Amanuban Barat dan 7 desa di Kecamatan Kie di Kabupaten TTS. Desa-Desa yang terpilih menjadi lokasi penelitian di Kecamatan Amanuban Barat 
adalah Desa Nusa, Desa Tublopo, Desa Nulle, Desa Pusu, Desa Mnelalete, Desa Haumenbaki, dan Desa Tubuhue, sedangkan di Kecamatan Kie adalah Desa Oenai, Desa Oinlasi, Desa Nekmese, Desa Falas, Desa Napi, Desa Enonapi, dan Desa Tesi Ayofanu. Populasi penelitian ini adalah anak berumur 6-60 bulan yang tercatat pada posyandu di Kecamatan Amanuban Barat dan Kie. Besar sampel dalam penelitian ini sebanyak 408 bayi berumur 6-24 bulan yang dipilih menggunakan teknik simple random sampling. Kriteria inklusi dalam penelitian ini adalah baduta bertempat tinggal di Kecamatan Amanuban Barat dan Kecamatan Kie, serta orangtua baduta bersedia menjadi responden penelitian dengan menandatangani informed consent, sedangkan kriteria eksklusi meliputi baduta yang mengalami sakit dan dirawat di sarana kesehatan, serta cacat fisik.

Variabel terikat yang diteliti adalah status stunting pada baduta, sedangkan variabel bebas, yaitu riwayat pemberian ASI eksklusif. Variabel luar yang juga diteliti meliputi riwayat pemberian kolostrum, riwayat berat badan lahir rendah (BBLR), asupan energi dan protein, serta karakteristik keluarga, meliputi pendidikan dan pekerjaan orang tua, serta jumlah anak tanggungan keluarga. Status stunting diperoleh dengan melakukan pengukuran panjang badan baduta dan ditentukan dengan indikator z-score standar baku WHO 2005. Status stunting dibedakan dalam 2 kategori, yaitu stunting jika nilai z-score $<-2$ SD dan tidak stunting jika nilai $z$-score $\geq-2 \mathrm{SD}$.

Data riwayat pemberian ASI eksklusif adalah pemberian ASI saja, kecuali vitamin, mineral, atau obat, baik berupa tetes maupun sirup, kepada baduta selama 6 bulan pertama kehidupannya. Data riwayat kolostrum adalah pemberian ASI yang pertama keluar oleh ibu kepada baduta. Data riwayat BBLR adalah baduta yang lahir dengan berat badan kurang dari 2.500 gram. Data asupan energi dan protein dikumpulkan menggunakan lembar food recall 24 jam. Asupan energi dan protein dikategorikan menjadi 2 berdasarkan angka kecukupan gizi (AKG) 2004, yaitu kurang jika persentase asupan energi dan protein $<80 \%$ AKG dan cukup jika persentase asupan energi dan protein $\geq 80 \%$ AKG.
Data pendidikan orang tua ialah jenjang pendidikan formal terakhir yang ditempuh ayah dan ibu, serta memperoleh ijazah, yang dibedakan dalam 2 kategori, yaitu rendah jika ayah atau ibu tidak tamat SD atau tamat SD dan SLTP dan tinggi jika tamat SLTA dan perguruan tinggi (D1, D3, S1, dan S2). Data pekerjaan ibu ialah pekerjaan yang dilakukan ibu dan menghasilkan uang, yang dibedakan dalam 4 kategori, yaitu petani/peternak/nelayan/buruh, karyawan swasta/PNS/TNI/polri dan wiraswasta, ibu rumah tangga/tidak bekerja, dan lain-lain. Data pekerjaan ayah ialah pekerjaan yang dilakukan ayah dan menghasilkan uang, yang dibedakan dalam 4 kategori, yaitu petani/peternak/nelayan/buruh, karyawan swasta/PNS/TNI/polri dan wiraswasta, tidak bekerja, dan lain-lain. Data jumlah anak tanggungan keluarga adalah jumlah anak yang tinggal bersama dalam satu rumah, dan menjadi tanggungan kepala rumah tangga, serta pengelolaan makan dari satu dapur yang dikategorikan menjadi 2 , yaitu banyak jika jumlah anak $>2$ orang dan sedikit jika jumlah anak $\leq 2$ orang. Data yang diperoleh selanjutnya akan diuji statistik bivariat menggunakan uji chi-square dan dilanjutkan dengan uji statistik multivariat menggunakan uji regresi logistik jika ada hubungan antara kejadian stunting pada baduta dengan riwayat pemberian ASI eksklusif.

\section{HASIL}

\section{Karakteristik subjek penelitian}

Dalam penelitian ini, total responden baduta sebanyak 408 orang, yang terdiri dari 203 laki-laki dan 205 perempuan. Persentase baduta berusia $\geq 12-24$ bulan di Kecamatan Amanuban Barat dan Kie masing-masing sebesar $61,8 \%$ dan $60,1 \%$ lebih tinggi dibandingkan dengan proporsi usia $<12$ bulan. Rata-rata berat badan dan panjang badan baduta, serta z-score panjang badan baduta menurut usia di Kecamatan Amanuban Barat dan Kie tidak menunjukkan perbedaan signifikan. Keluarga yang memiliki tanggungan anak $>2$ orang lebih banyak bertempat tinggal di Kecamatan Amanuban Barat dibandingkan dengan Kie. Secara rerata, pengeluaran rumah tangga, usia ibu dan usia ayah antara dua kecamatan ini berbeda signifikan. Persentase ayah dan ibu yang berpendidikan 
tinggi lebih banyak bertempat tinggal di Kecamatan Amanuban Barat dibandingkan dengan di Kie. Jika ditinjau dari segi pekerjaan ibu, maka pekerjaan ibu rumah tangga/tidak bekerja memiliki persentase tertinggi dibandingkan dengan pekerjaan lain, sedangkan sebagian besar ayah bekerja sebagai petani/peternak/nelayan/buruh di Kecamatan Amanuban Barat dan Kie (Tabel 1).

Proporsi baduta yang menerima ASI eksklusif di dua kecamatan yang menjadi lokasi penelitian sebesar $61 \%$ dengan pembagian Kecamatan Kie $(66,7 \%)$ lebih tinggi dibandingkan dengan Amanuban Barat $(56,4 \%)$. Secara keseluruhan persentase pemberian MPASI dini sebesar $36,8 \%$. Jika dibagi berdasarkan kecamatan, persentase pemberian MPASI sebelum usia 6 bulan di Kecamatan Amanuban Barat lebih tinggi dibandingkan dengan Kie. Persentase pemberian ASI eksklusif yang tinggi di Kie didukung juga dengan pemberian kolostrum yang tinggi di Kie dibandingkan dengan Amanuban Barat. Delapan baduta tidak memiliki data berat badan lahir karena ibu melahirkan di rumah sehingga berat badan lahir tidak ditimbang. Persentase baduta yang memiliki riwayat BBLR lebih tinggi di Kecamatan Kie (14,9\%), sedangkan persentase baduta yang cukup mendapatkan asupan energi dan protein lebih tinggi di Kecamatan Amanuban Barat (Tabel 2). Hasil penelitian ini menunjukkan proporsi baduta yang mengalami stunting sebesar $49 \%$. Jika dibagi berdasarkan kecamatan, proporsi baduta stunting di Kecamatan Kie $(50,3 \%)$ lebih tinggi dibandingkan dengan di Amanuban Barat (48\%) (Gambar 1).

\section{Faktor-faktor prediktor stunting}

Secara statistik, pemberian ASI eksklusif tidak memiliki hubungan dengan kejadian stunting $(p=0,53)$. Hasil yang sama juga diperoleh pada pemberian MPASI dini $(p=0,48)$. Pemberian kolostrum dan riwayat $B B L R$ tidak memiliki hubungan yang bermakna dengan kejadian stunting. Asupan energi berhubungan bermakna dengan kejadian stunting $(p=0,04)$, sedangkan asupan protein tidak berhubungan bermakna dengan kejadian stunting $(p=0,19)$. Pendidikan dan pekerjaan orang tua berhubungan bermakna dengan kejadian stunting, sedangkan jumlah anak dalam rumah tangga tidak berhubungan bermakna dengan kejadian stunting (Tabel 3). Dalam analisis multivariabel, pemberian ASI eksklusif dan MPASI dini tidak berhubungan signifikan dengan kejadian stunting, walaupun variabel-variabel lain telah dikontrol (Tabel 4).

\section{BAHASAN}

Proporsi baduta yang mengalami stunting sebesar $49 \%$. Proporsi baduta yang menerima ASI eksklusif di dua kecamatan yang menjadi lokasi penelitian sebesar $61 \%$ dengan pembagian Kecamatan Kie $(66,7 \%)$ lebih tinggi dibandingkan dengan Amanuban Barat (56,4\%). Secara nasional, pemberian ASI eksklusif sampai umur 4-5 bulan mencapai $31 \%$ (12). Proporsi pemberian ASI eksklusif lebih kecil ditemukan di Pulau Nias sebesar 12\% (13). Hasil penelitian ini menunjukkan persentase pemberian MPASI dini sebesar $36,8 \%$. Jika dibagi berdasarkan kecamatan, persentase pemberian MPASI sebelum usia 6 bulan di Kecamatan Amanuban Barat (42,7\%) lebih tinggi dibandingkan dengan Kie (29,5\%).

Hasil analisis bivariabel menunjukkan pemberian ASI eksklusif tidak memiliki hubungan dengan kejadian stunting $(p=0,53)$. Hasil yang sama juga diperoleh pada pemberian MPASI dini ( $p=$ $0,48)$. Pemberian kolostrum dan riwayat BBLR tidak memiliki hubungan yang bermakna dengan kejadian stunting. Asupan energi berhubungan bermakna dengan kejadian stunting $(p=0,04)$, sedangkan asupan protein tidak berhubungan bermakna dengan kejadian stunting $(p=0,19)$. Pendidikan dan pekerjaan orang tua berhubungan bermakna dengan kejadian stunting, sedangkan jumlah anak dalam rumah tangga tidak berhubungan bermakna dengan kejadian stunting. Analisis multivariabel menunjukkan pemberian ASI eksklusif tidak berhubungan signifikan dengan kejadian stunting $(\mathrm{OR}=1,25 ; 95 \% \mathrm{Cl}=0,75-2,07)$. Hasil yang sama juga diperoleh pada pemberian MPASI dini $(\mathrm{OR}=1,04$; $95 \% \mathrm{Cl}=0,62-1,72$ ).

Beberapa penelitian menunjukkan pemberian ASI eksklusif $(14,15)$ dan MPASI dini $(16,17)$ tidak 
Tabel 1. Karakteristik dasar responden penelitian berdasarkan kecamatan

\begin{tabular}{|c|c|c|c|c|c|c|}
\hline \multirow{3}{*}{ Karakteristik responden } & \multicolumn{4}{|c|}{ Kecamatan } & \multirow{3}{*}{$\chi^{2} / \mathbf{t}$} & \multirow{3}{*}{$p$} \\
\hline & \multicolumn{2}{|c|}{ Amanuban Barat } & \multicolumn{2}{|c|}{ Kie } & & \\
\hline & $\mathbf{n}$ & $\%$ & $\mathbf{n}$ & $\%$ & & \\
\hline \multicolumn{7}{|l|}{ Jenis kelamin baduta } \\
\hline Laki-laki & 110 & 48,9 & 93 & 50,8 & \multirow[t]{2}{*}{0,08} & \multirow[t]{2}{*}{0,77} \\
\hline Perempuan & 115 & 51,1 & 90 & 49,2 & & \\
\hline \multicolumn{7}{|l|}{ Kategori usia baduta } \\
\hline$<12$ bulan & 86 & 38,2 & 73 & 39,9 & \multirow[t]{2}{*}{0,06} & \multirow[t]{2}{*}{0,81} \\
\hline$\geq 12-24$ bulan & 139 & 61,8 & 110 & 60,1 & & \\
\hline \multicolumn{7}{|l|}{ Berat badan baduta } \\
\hline Mean \pm SD & \multicolumn{2}{|c|}{$8,42 \pm 1,40$} & \multicolumn{2}{|c|}{$8,19 \pm 1,27$} & 1,74 & 0,07 \\
\hline \multicolumn{7}{|l|}{ Panjang badan baduta } \\
\hline Mean \pm SD & \multicolumn{2}{|c|}{$72,83 \pm 5,69$} & \multicolumn{2}{|c|}{$71,80 \pm 5,59$} & 1,84 & 0,66 \\
\hline \multicolumn{7}{|l|}{ Z-score baduta berdasarkan PB/U } \\
\hline Mean \pm SD & \multicolumn{2}{|c|}{$-1,64 \pm 1,68$} & \multicolumn{2}{|c|}{$-1,78 \pm 1,54$} & 0,86 & 0,23 \\
\hline \multicolumn{7}{|l|}{ Jumlah anak tanggungan keluarga } \\
\hline$>2$ orang & 111 & 49,3 & 90 & 49,2 & 0,00 & 1,00 \\
\hline$\leq 2$ orang & 114 & 50,7 & 93 & 50,8 & & \\
\hline Pengasuh anak & & & & & & \\
\hline Bukan ibu kandung & 20 & 8,9 & 6 & 3,3 & 5,32 & 0,02 \\
\hline Ibu kandung & 205 & 91,1 & 177 & 96 & & \\
\hline Kategori usia ibu/pengasuh & & & & & & \\
\hline$<25$ dan $>35$ & 108 & 48,0 & 78 & 42,6 & 0,97 & 0,33 \\
\hline $25-35$ & 117 & 52,0 & 105 & 57,4 & & \\
\hline Usia ibu/pengasuh & & & & & & \\
\hline Mean \pm SD & 31 , & 3,54 & 30,4 & 7,37 & 0,70 & 0,03 \\
\hline Pendidikan terakhir ibu/pengasuh & & & & & & \\
\hline Rendah & 164 & 72,9 & 157 & 85,8 & 9,26 & 0,02 \\
\hline Tinggi & 61 & 27,1 & 26 & 14,2 & & \\
\hline Pekerjaan ibu/pengasuh & & & & & & \\
\hline Petani/peternak/nelayan/buruh & 24 & 10,7 & 20 & 10,9 & & \\
\hline Karyawan swasta/PNS/TNI/polri dan wiraswasta & 8 & 3,6 & 1 & 0,5 & 5,52 & 0,14 \\
\hline Ibu rumah tangga/tidak bekerja & 187 & 83,1 & 159 & 86,9 & & \\
\hline Lain-lain* & 6 & 2,7 & 3 & 1,6 & & \\
\hline Kategori usia ayah** & & & & & & \\
\hline$<25$ dan $\geq 40$ & 84 & 38,0 & 56 & 31,3 & 1,68 & 0,20 \\
\hline $25-39$ & 137 & 62,0 & 123 & 68,7 & & \\
\hline Usia ayah & & & & & & \\
\hline Mean \pm SD & 34 , & 9,43 & 34,6 & 7,81 & 0,03 & 0,03 \\
\hline Pendidikan terakhir ayah ${ }^{* *}$ & & & & & & \\
\hline Rendah & 143 & 64,7 & 143 & 79,9 & 10,45 & 0,001 \\
\hline Tinggi & 78 & 35,3 & 36 & 20,1 & & \\
\hline Pekerjaan ayah** & & & & & & \\
\hline Petani/peternak/nelayan/buruh & 156 & 70,6 & 162 & 90,5 & 25,68 & 0,000 \\
\hline Karyawan swasta/PNS/TNI/polri dan wiraswasta & 53 & 24,0 & 14 & 7,8 & & \\
\hline Tidak bekerja & 4 & 1,8 & 1 & 0,6 & & \\
\hline Lain-lain* & 8 & 3,6 & 2 & 1,1 & & \\
\hline
\end{tabular}


dari halaman 57

Pengeluaran rumah tangga

Mean \pm SD

$\begin{array}{cccc}\operatorname{Rp~610611\pm } & \operatorname{Rp~435106\pm } & 4,86 & 0,000 \\ 427472 & 300566 & & \end{array}$

Pengeluaran rumah tangga berdasarkan $\mathrm{UMR}^{* * *}$

$<\operatorname{Rp} 850.000$

$174 \quad 77,3 \quad 168 \quad 91,8 \quad 14,53 \quad 0,000$

$\geq \operatorname{Rp} 850.000$

$51 \quad 22,7 \quad 15 \quad 8,2$

Keterangan:

* Lain-lain adalah pelajar, mahasiswa, pendeta, dan tenaga honorer pemerintahan

* Subjek yang masih memiliki ayah sebanyak 400 baduta. Delapan subyek tidak tinggal bersama ayah disebabkan oleh ayah meninggal dunia (2 subjek) dan ayah tidak lagi tinggal serumah/ayah tidak lagi menanggung ekonomi rumah tangga (6 subjek).

*** Upah Minimum Regional Provinsi NTT tahun 2012 sebesar Rp 850.000,-

Tabel 2. Karakteristik responden menurut pemberian ASI eksklusif dan asupan zat gizi berdasarkan kecamatan

\begin{tabular}{|c|c|c|c|c|c|c|}
\hline \multirow{3}{*}{ Karakteristik responden } & \multicolumn{4}{|c|}{ Kecamatan } & \multirow{3}{*}{$\chi^{2}$} & \multirow{3}{*}{$p$} \\
\hline & \multicolumn{2}{|c|}{ Amanuban Barat } & \multicolumn{2}{|c|}{ Kie } & & \\
\hline & $\mathbf{n}$ & $\%$ & $\mathbf{n}$ & $\%$ & & \\
\hline \multicolumn{7}{|l|}{ Pemberian ASI eksklusif } \\
\hline Tidak & 98 & 43,6 & 61 & 33,3 & 4,43 & 0,04 \\
\hline $\mathrm{Ya}$ & 127 & 56,4 & 122 & 66,7 & & \\
\hline \multicolumn{7}{|l|}{ Pemberian MPASI dini } \\
\hline $\mathrm{Ya}$ & 96 & 42,7 & 54 & 29,5 & 7,52 & 0,006 \\
\hline Tidak & 129 & 57,3 & 129 & 70,5 & & \\
\hline \multicolumn{7}{|l|}{ Pemberian kolostrum } \\
\hline Tidak & 29 & 12,9 & 12 & 6,6 & 3,80 & 0,05 \\
\hline Ya & 196 & 87,1 & 171 & 93,4 & & \\
\hline \multicolumn{7}{|l|}{ Riwayat BBLR* } \\
\hline$<2.500 \mathrm{~g}$ & 14 & 6,4 & 27 & 14,9 & 6,93 & 0,008 \\
\hline$\geq 2.500 \mathrm{~g}$ & 205 & 93,6 & 154 & 85,1 & & \\
\hline \multicolumn{7}{|l|}{ Asupan energi } \\
\hline$<80 \%$ AKG & 87 & 38,7 & 75 & 41,0 & 0,14 & 0,71 \\
\hline$\geq 80 \%$ AKG & 138 & 61,3 & 108 & 59,0 & & \\
\hline \multicolumn{7}{|l|}{ Asupan protein } \\
\hline$<80 \%$ AKG & 91 & 40,4 & 69 & 37,7 & 0,21 & 0,64 \\
\hline$\geq 80 \%$ AKG & 134 & 59,6 & 114 & 62,3 & & \\
\hline
\end{tabular}

Keterangan:

* Delapan subjek tidak memiliki data berat badan lahir karena melahirkan di rumah

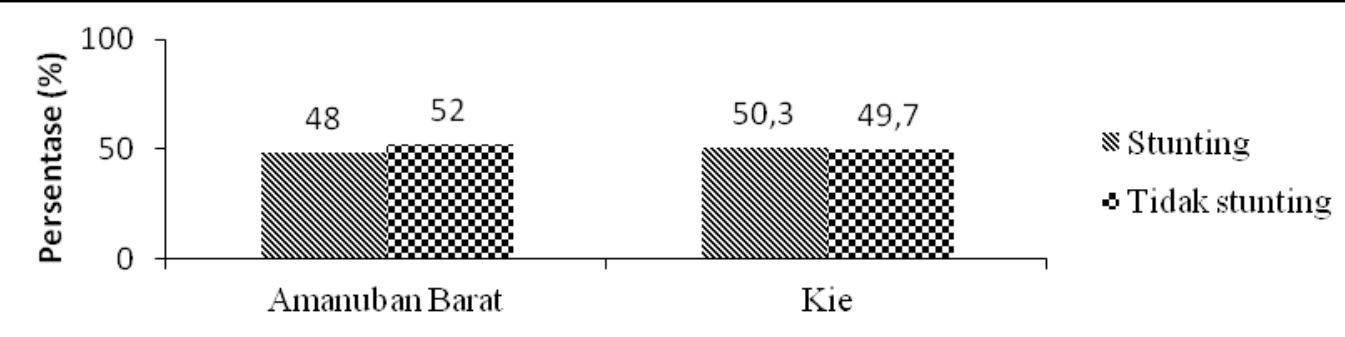

Gambar 1. Proporsi baduta yang mengalami stunting dan tidak stunting 
Tabel 3. Analisis faktor-faktor prediktor stunting

\begin{tabular}{|c|c|c|c|c|c|c|c|}
\hline \multirow{3}{*}{ Variabel } & \multicolumn{4}{|c|}{$\begin{array}{l}\text { Status gizi berdasarkan panjang } \\
\text { badan menurut usia (PB/U) }\end{array}$} & \multirow{3}{*}{$\chi^{2}$} & \multirow{3}{*}{$p$} & \multirow{3}{*}{$\begin{array}{c}\text { RP } \\
(95 \% \mathrm{Cl})\end{array}$} \\
\hline & \multicolumn{2}{|c|}{ Stunting } & \multicolumn{2}{|c|}{ Tidak stunting } & & & \\
\hline & $\mathbf{n}$ & $\%$ & $\mathbf{n}$ & $\%$ & & & \\
\hline \multicolumn{8}{|l|}{ Pemberian ASI eksklusif } \\
\hline Tidak & 81 & 40,5 & 78 & 37,5 & 0,39 & 0,53 & 1,08 \\
\hline Ya & 119 & 59,5 & 130 & 62,5 & & & $(0,85-1,38)$ \\
\hline \multicolumn{8}{|l|}{ Pemberian MPASI dini } \\
\hline$\leq 6$ bulan & 77 & 38,5 & 73 & 35,1 & 0,51 & 0,48 & 1,10 \\
\hline$>6$ bulan & 123 & 61,5 & 135 & 64,9 & & & $(0,85-1,42)$ \\
\hline \multicolumn{8}{|l|}{ Pemberian kolostrum } \\
\hline Tidak & 24 & 12,0 & 17 & 8,2 & 1,65 & 0,20 & 1,47 \\
\hline Ya & 176 & 88,0 & 191 & 91,8 & & & $(0,81-2,65)$ \\
\hline \multicolumn{8}{|l|}{ Riwayat BBLR } \\
\hline$<2.500 \mathrm{~g}$ & 18 & 9,1 & 23 & 11,3 & 0,52 & 0,47 & 0,81 \\
\hline$\geq 2.500 \mathrm{~g}$ & 179 & 90,9 & 180 & 88,7 & & & $(0,45-1,45)$ \\
\hline \multicolumn{8}{|l|}{ Asupan energi } \\
\hline$<80 \%$ AKG & 69 & 34,5 & 93 & 44,7 & 4,44 & 0,04 & 0,77 \\
\hline$\geq 80 \%$ AKG & 131 & 65,5 & 115 & 55,3 & & & $(0,61-0,98)$ \\
\hline \multicolumn{8}{|l|}{ Asupan protein } \\
\hline$<80 \%$ AKG & 72 & 36,0 & 88 & 42,3 & 1,70 & 0,19 & 0,85 \\
\hline$\geq 80 \%$ AKG & 128 & 64,0 & 120 & 57,7 & & & $(0,67-1,09)$ \\
\hline \multicolumn{8}{|l|}{ Pendidikan ibu } \\
\hline Rendah & 171 & 85,5 & 150 & 72,1 & 10,89 & 0,001 & 1,18 \\
\hline Tinggi & 29 & 14,5 & 58 & 27,9 & & & $(1,07-1,31)$ \\
\hline \multicolumn{8}{|l|}{ Pendidikan ayah } \\
\hline Rendah & 150 & 76,9 & 136 & 66,3 & 5,49 & 0,02 & 1,16 \\
\hline Tinggi & 45 & 23,1 & 69 & 33,7 & & & $(1,02-1,31)$ \\
\hline \multicolumn{8}{|l|}{ Jumlah anak tanggungan keluarga } \\
\hline$>2$ orang & 91 & 45,5 & 110 & 52,9 & 2,23 & 0,14 & 0,86 \\
\hline$\leq 2$ orang & 109 & 54,5 & 98 & 47,1 & & & $(0,71-1,05)$ \\
\hline \multicolumn{8}{|l|}{ Pekerjaan ibu } \\
\hline Petani/peternak/nelayan/buruh & 24 & 12,0 & 20 & 9,6 & 8,43 & 0,04 & - \\
\hline $\begin{array}{l}\text { Karyawan swasta/PNS/TNI/polri dan } \\
\text { wiraswasta }\end{array}$ & 2 & 1,0 & 7 & 3,4 & & & \\
\hline Ibu rumah tangga/tidak bekerja & 173 & 86,5 & 173 & 83,2 & & & \\
\hline Lain-lain & 1 & 0,5 & 8 & 3,8 & & & \\
\hline \multicolumn{8}{|l|}{ Pekerjaan ayah } \\
\hline Petani/peternak/nelayan/buruh & 167 & 85,6 & 151 & 73,7 & 10,26 & 0,02 & - \\
\hline $\begin{array}{l}\text { Karyawan swasta/PNS/TNI/polri } \\
\text { dan wiraswasta }\end{array}$ & 22 & 11,3 & 45 & 22,0 & & & \\
\hline Tidak bekerja & 3 & 1,5 & 2 & 1,0 & & & \\
\hline Lain-lain & 3 & 1,5 & 7 & 3,4 & & & \\
\hline
\end{tabular}

berhubungan signifikan dengan kejadian stunting. Hasil penelitian ini dapat disebabkan oleh beberapa hal, di antaranya pengetahuan ibu yang rendah tentang ASI eksklusif dan MPASI dini. Hasil FGD menunjukkan banyak ibu tidak mengetahui manfaat pemberian ASI eksklusif bagi pertumbuhan anak. Beberapa penelitian menunjukkan pengetahuan ibu tentang ASI eksklusif mempengaruhi ibu untuk memberikan ASI eksklusif $(18,19)$. Hasil FGD juga menunjukkan ibu tidak mengetahui tahapan pemberian MPASI yang tepat sehingga pemberian MPASI tidak sesuai dengan umur.

Faktor penyebab lain adalah kualitas pemberian ASI kepada anak. Kualitas pemberian 
48 Asweros Umbu Zogara, Hamam Hadi, Tony Arjuna

Tabel 4. Analisis multivariabel faktor-faktor prediktor stunting

\begin{tabular}{|c|c|c|c|}
\hline Variabel & $\begin{array}{c}\text { Model } 1 \\
\text { OR } \\
(95 \% \mathrm{Cl}) \\
\end{array}$ & $\begin{array}{c}\text { Model } 2 \\
\text { OR } \\
(95 \% \mathrm{Cl}) \\
\end{array}$ & $\begin{array}{c}\text { Model } 3 \\
\text { OR } \\
(95 \% \mathrm{Cl}) \\
\end{array}$ \\
\hline $\begin{array}{l}\text { Pemberian ASI eksklusif } \\
\text { Tidak }\end{array}$ & $\begin{array}{c}1,25 \\
(0,75-2,07)\end{array}$ & $\begin{array}{c}1,18 \\
(0,72-1,92)\end{array}$ & $\begin{array}{c}1,06 \\
(0,66-1,72)\end{array}$ \\
\hline Ya & 1 & 1 & 1 \\
\hline $\begin{array}{l}\text { Pemberian MPASI dini } \\
\text { Tidak }\end{array}$ & $\begin{array}{c}1,04 \\
(0,62-1,72)\end{array}$ & $\begin{array}{c}1,10 \\
(0,68-1,80)\end{array}$ & $\begin{array}{c}1,01 \\
(0,62-1,65)\end{array}$ \\
\hline $\mathrm{Ya}$ & 1 & 1 & 1 \\
\hline $\begin{array}{l}\text { Pemberian kolostrum } \\
\text { Tidak }\end{array}$ & $\begin{array}{c}1,49 \\
(0,71-3,12)\end{array}$ & & $\begin{array}{c}0,87 \\
(0,58-1,32)\end{array}$ \\
\hline Ya & 1 & & 1 \\
\hline $\begin{array}{r}\text { Riwayat BBLR } \\
<2.500 \mathrm{~g}\end{array}$ & $\begin{array}{c}1,82 \\
(0,90-3,67)\end{array}$ & & $\begin{array}{c}1,26 \\
(0,65-2,43)\end{array}$ \\
\hline$\geq 2.500 \mathrm{~g}$ & 1 & & 1 \\
\hline $\begin{array}{l}\text { Asupan energi } \\
<80 \% \text { AKG }\end{array}$ & $\begin{array}{c}1,42 \\
(0,84-2,43)\end{array}$ & & $\begin{array}{c}1,39 \\
(0,85-2,28)\end{array}$ \\
\hline $\begin{array}{l}\quad \geq 80 \% \text { AKG } \\
\text { Asupan protein }\end{array}$ & 1 & & 1 \\
\hline$<80 \%$ AKG & $\begin{array}{c}1,23 \\
(0,73-2,13)\end{array}$ & & $\begin{array}{c}1,01 \\
(0,61-1,67)\end{array}$ \\
\hline$\geq 80 \%$ AKG & 1 & & 1 \\
\hline $\begin{array}{c}\text { Pendidikan ibu } \\
\text { Rendah }\end{array}$ & $\begin{array}{c}1,76 \\
(0,99-3,12)\end{array}$ & $\begin{array}{c}1,88^{*} \\
(1,07-3,30)\end{array}$ & \\
\hline $\begin{array}{c}\text { Tinggi } \\
\text { Pendidikan ayah }\end{array}$ & 1 & 1 & \\
\hline Rendah & $\begin{array}{c}1,23 \\
(0,72-2,09)\end{array}$ & $\begin{array}{c}1,16 \\
(0,69-1,94)\end{array}$ & \\
\hline Tinggi & 1 & & \\
\hline $\begin{array}{l}\text { Jumlah anak tanggungan keluarga } \\
\qquad>2 \text { orang }\end{array}$ & $\begin{array}{c}1,52 \\
(0,99-2,31)\end{array}$ & $\begin{array}{c}1,5 \\
(1,00-2,26)\end{array}$ & \\
\hline $\begin{array}{l}\leq 2 \text { orang } \\
\text { Pekerjaan ibu }\end{array}$ & 1 & 1 & \\
\hline Petani/peternak/nelayan/buruh & $\begin{array}{c}0,27 \\
(0,06-1,22)\end{array}$ & $\begin{array}{c}0,45 \\
(0,11-1,83)\end{array}$ & \\
\hline $\begin{array}{l}\text { Karyawan swasta/PNS/TNI/ } \\
\text { polri\&wiraswasta }\end{array}$ & $\begin{array}{c}0,40 \\
(0,05-3,54)\end{array}$ & $\begin{array}{c}0,74 \\
(0.09-5,91)\end{array}$ & \\
\hline Ibu rumah tangga/tidak bekerja & $\begin{array}{c}0,28 \\
(0,07-1,08)\end{array}$ & $\begin{array}{c}0,47 \\
(0,14-1,64)\end{array}$ & \\
\hline Lain-lain & 1 & 1 & \\
\hline $\begin{array}{l}\text { Pekerjaan ayah } \\
\text { Petani/peternak/nelayan/buruh }\end{array}$ & $\begin{array}{c}0,98 \\
(0,26-3,71)\end{array}$ & $\begin{array}{c}1,17 \\
(0,35-3,96)\end{array}$ & \\
\hline $\begin{array}{l}\text { Karyawan swasta/PNS/TNI/ } \\
\text { polri\&wiraswasta }\end{array}$ & $\begin{array}{c}1,92 \\
(0,48-7,67)\end{array}$ & $\begin{array}{c}1,96 \\
(0,54-7,12)\end{array}$ & \\
\hline Tidak bekerja & $\begin{array}{c}0,82 \\
(0,09-7,75)\end{array}$ & $\begin{array}{c}0,81 \\
(0,09-7,34)\end{array}$ & \\
\hline Lain-lain & 1 & 1 & \\
\hline
\end{tabular}


ASI yang rendah dapat disebabkan oleh ibu tidak memberikan ASI secara konsisten, terutama karena ibu harus kembali bekerja dan adanya kebiasaan ibu yang memberikan makanan/minuman lain kepada anak saat anak sakit. Kualitas dan kuantitas MPASI yang rendah juga mempengaruhi hasil penelitian ini. Kualitas MPASI yang rendah dipengaruhi oleh kurangnya variasi makanan yang diberikan kepada anak dan ibu tidak memperhatikan kebersihan makanan yang diberikan kepada anak. Kuantitas MPASI yang rendah dipengaruhi oleh ibu yang tidak memperhatikan jumlah makanan yang dikonsumsi anak dan rendahnya rata-rata asupan zat gizi makro.

Dalam penelitian ini, karakteristik orang tua, meliputi pendidikan dan pekerjaan orang tua berhubungan signifikan dengan kejadian stunting pada baduta. Tingkat pendidikan ayah dan ibu merupakan faktor protektif perilaku kesehatan dalam merawat anak. Tingkat pendidikan ayah dan ibu mempengaruhi pengetahuan dan perilaku ayah dan ibu dalam menjaga kesehatan anak, misalnya penggunaan jamban, imunisasi rutin, mengonsumsi kapsul vitamin A, menggunakan garam beryodium, dan selalu ke posyandu (20). Hasil ini sama dengan beberapa penelitian yang menunjukkan hubungan yang signifikan antara pendidikan ibu dan ayah dengan kejadian stunting $(21,22)$.

Pekerjaan orang tua berkaitan erat dengan kondisi ekonomi keluarga. Penelitian ini menunjukkan banyak ibu yang juga tidak bekerja dan sebagian besar ayah bekerja sebagai petani dengan penghasilan yang tidak menentu. Hal ini menyebabkan banyak keluarga yang berada pada kondisi ekonomi rendah. Kondisi ekonomi keluarga yang rendah akan menyulitkan ibu untuk membeli dan menyiapkan makanan yang bergizi untuk anak sehingga anak akan mengalami ketidakcukupan asupan zat gizi.

\section{KESIMPULAN DAN SARAN}

Proporsi stunting pada baduta di Kecamatan Amanuban Barat dan Kie sebesar 49\%. Secara keseluruhan proporsi pemberian ASI eksklusif sebesar $61 \%$, sedangkan proporsi pemberian
MPASI dini sebesar 36,8\%. Pemberian ASI eksklusif bukan merupakan prediktor terjadinya stunting di Kecamatan Amanuban Barat dan Kie. Faktor-faktor lain yang dapat memprediksi terjadinya stunting pada baduta adalah asupan energi dan karakteristik orang tua, yang meliputi pendidikan dan pekerjaan orang tua.

Saran bagi pemerintah Kabupaten TTS agar memperhatikan dan menjamin akses masyarakat terhadap makanan karena mahalnya harga makanan di desa-desa yang berlokasi jauh dari Kota Soe. Kondisi ekonomi sebagian besar masyarakat yang rendah akan menyulitkan masyarakat membeli makanan sehingga distribusi makanan di tingkat rumah tangga tidak merata. Distribusi makanan yang tidak merata akan mengurangi asupan zat gizi, termasuk asupan energi yang menjadi prediktor stunting sehingga berakibat pada terjadinya masalah gizi.

Saran bagi Dinas Kesehatan Kabupaten TTS agar melakukan edukasi kepada masyarakat, terutama ibu yang berpendidikan rendah, berkaitan dengan pola asuh anak dan gizi sehingga mampu meningkatkan kualitas pemberian ASI, serta kualitas dan kuantitas MPASI. Edukasi juga dilakukan kepada ayah, terutama ayah yang berpendidikan rendah, sehingga lebih mampu memahami dan memperhatikan kebutuhan gizi anak.

\section{RUJUKAN}

1. Stevens GA, Finucane MM, Paciorek CJ, Flaxman SR, White RA, Donner AJ, Ezzati, M. Trends in mild, moderate, and severe stunting and underweight, and progress towards MDG 1 in 141 developing countries: A systematic analysis of population representative data. The Lancet 2012; 380: 824-34.

2. Depkes RI. Laporan Riset Kesehatan Dasar. Jakarta: Badan Penelitian dan Pengembangan Kesehatan; 2010.

3. Victora CG, Adair L, Fall C, Hallal PC, Martorell R, Richter L, Sachdev HS. Maternal and child undernutrition: consequences for adult health and human capital. The Lancet 2008; 371: 340-57. 
4. Hien NN, Hoa NN. Nutritional status and determinants of malnutrition in children under three years of age in Nghean, Vietnam. Pakistan Journal of Nutrition 2009;8(7): 958-964.

5. Hien NN, Kam S. Nutritional status and the characteristics related to malnutrition in children under five years of age in Nghean, Vietnam. Journal of Preventive Medicine and Public Health 2008;41(4): 232-240.

6. Ismawaty N, Djais J, Garna, H. Effect of exclusive breast-feeding on the linear growth of children aged 24-36 months in Bandung's urban slum area. Paediatrica Indonesiana 2008;48(3): 120-124.

7. Kramer MS, Guo T, Platt RW, Sevkovskaya Z, Dzikovich I, Collet JP, Shapiro S, Chalmers B, Hodnett E, Vanilovich I, Mezen I, Ducruet T, Shishko G, Bogdanovich N. Infant growth and health outcomes associated with 3 compared with 6 mo of exclusive breastfeeding. The American Journal of Clinical Nutrition 2008;78: 291-5.

8. Brennan L, McDonald J, Shlomowitz R. Infant feeding practices and chronic child malnutrition in the Indian states of Karnataka and Uttar Pradesh. Economics and Human Biology 2004;2:139-158.

9. Teshome B, Kogi-Makau W, Getahun Z, \& Taye $G$. Magnitude and determinants of stunting in children underfive years of age in food surplus region of Ethiopia: The case of West Gojam Zone. The Ethiopian Journal of Health Development 2009;23(2): 98-106.

10. Depkes RI. Laporan Riset Kesehatan Dasar 2007 Provinsi Nusa Tenggara Timur. Jakarta: Badan Penelitian dan Pengembangan Kesehatan; 2008.

11. FAO, UNICEF, \& WFP. Nutrition security and food security in seven districts in NTT Province, Indonesia: Status, causes and recommendations for response. Jakarta \& Roma; 2010.

12. Depkes RI. Laporan Riset Kesehatan Dasar 2010. Jakarta: Badan Penelitian dan Pengembangan Kesehatan; 2010.

13. Inayati DA, Scherbaum V, Purwestri RC, Hormann E, Wirawan NN, Suryantan J, Hartono S, Bloem MA, Pangaribuan RV, Biesalski HK, Hoffmann V, \& Bellows C. Infant feeding practices among mildly wasted children: a retrospective study on Nias Island, Indonesia. International Breastfeeding Journal 2012;7: 3.

14. Ajao KO, Ojofeitimi EO, Adebayo AA., Fatusi AO, Afolabi OT. Influence of family size, household food security status, and child care practices on the nutritional status of under-five children in Ile-Ife, Nigeria. African Journal of Reproductive Health 2010;14(4): 123-132.

15. Kumar D, Goel NK, Mittal PC, Misra P. Influence of infant-feeding practices on nutritional status of under-five children. Indian Journal of Pediatrics 2006;73(5): 417-421.

16. Gupta N, Gehri M, Stettler N. Early introduction of water and complementary feeding and nutritional status of children in Northern Senegal. Public Health Nutrition 2007;10(11): 1299-1304.

17. Umeta M, West CE, Verhoef $\mathrm{H}$, Haidar J, Hautvast JGAJ. Factors associated with stunting in infants aged 5-11 months in the Dodota-Sire District, Rural Ethiopia. The Journal of Nutrition 2003;133: 1064-1069.

18. Nkala TE \& Msuya SE. Prevalence and predictors of exclusive breastfeeding among women in Kigoma region, Western Tanzania: a community based crosssectional study. International Breastfeeding Journal 2011;6: 17.

19. Ulak M, Chandyo RK, Mellander L, Shrestha PS, Strand TA. Infant feeding practices in Bhaktapur, Nepal: across-sectional, health facility based survey. International Breastfeeding Journal 2012;7:1.

20. Semba RD, de Pee S, Sun K, Sari M, Akhter N, Bloem M. Effect of parental formal education on risk of child stunting in Indonesia and Bangladesh: a cross-sectional study. The Lancet 2008;371: 322-28.

21. Hong R, Mishra V. Effect of wealth inequality on chronic under-nutrition in Cambodian children. Journal of Health, Population, and Nutrition 2006;24(1): 89-99.

22. Ergin F, Okyay P, Atasoylu G, Beser, E. Nutritional status and risk factors of chronic malnutrition in children under five years of age in Aydın, a western city of Turkey. The Turkish Journal of Pediatrics 2007;49: 283-289. 